\title{
ISTRAŽNI ODBORI EVROPSKOG PARLAMENTA - KORISTAN INSTRUMENT KONTROLE PRIMENE KOMUNITARNOG PRAVA
}

\begin{abstract}
Ninoslav ŽIVKOVIĆ*
Apstrakt: Shodno nacionalnim zakonodavstvima, u komunitarnom pravu takođe postoji mogućnost formiranja odbora u cilju sprovođenja istrage o konkretnom pitanju. Na taj način se ostvaruje tradicionalna parlamentarna uloga nadzora nad izvršnom vlašću. Istražna tela Evropskog parlamenta su refleksija kontrolne funkcije i uvećanih zakonodavnih prerogativa ovog organa. Iako je rezultat njihovog delovanja izrada izveštaja koji je neobavezne pravne prirode, značaj ovih tela je vidljiv kako na institucionalnoj ravni (odnos Evropski parlament - Evropska komisija), tako i u pogledu podsticanja legislativnih promena u Evropskoj uniji. Cilj rada je demistifikacija specifične oblasti kako bi se upotrebom istorijskog i teleološkog tumačenja, kao i konceptualne analize, istakla važna uloga odbora u otkrivanju brojnih štetnih uticaja po komunitarno pravo.

Ključne reči: Istražni odbor, komunitarno pravo, Evropski parlament, Evropska Komisija, Evropska unija.
\end{abstract}

\section{1) UVOD}

Jedan od načina vršenja kontrolne funkcije Evropskog parlamenta ${ }^{1}(\mathrm{u}$ daljem tekstu Parlament) jeste formiranje istražnih odbora, kako bi se obezbedila adekvatna primena prava Unije od strane njenih članica i institucija. U slučajevima gde je, usled kršenja komunitarnog prava, prisutan tzv. „deficit odgovornosti”, ova

\footnotetext{
* Master pravnik, doktorand iz međunarodnopravne uže naučne oblasti (oblast međunarodnog javnog prava) na Pravnom fakultetu Univerziteta u Beogradu. Ovaj članak je rezultat naučnog istraživanja komunitarnog prava iz oblasti istražnih komisija Evropskog parlamenta, bliskoj okvirnoj temi doktorske disertacije doktoranda. E-mail: ninoslavzivkovic7@gmail.com

1 "Treaty of Lisbon Amending the Treaty on European Union and the Treaty Establishing the European Community", 13 December 2007, 2007/C 306/01, article 9A.

${ }^{2}$ Corina Andone, "Argumentative Patterns in the Political Domain: The Case of European Parliamentary Committees of Inquiry", Argumentation, Vol. 30, No. 1, 2016, p. 45.
} 
tela doprinose efikasnom otklanjanju nepravilnosti. Namera autora je da ih predstavi kao svrsishodna i korisna sredstva kojima se Parlament služi u praksi. Njihov značaj nije ograničen isključivo na istražne radnje, uočavanje i preciziranje malformacija u pravu Evropske unije (u daljem tekstu EU), kako bi se osigurala konzistentna primena istog. Korišćenjem ovih tela Evropski parlament se pozicionira odmah uz Evropsku Komisiju (u daljem tekstu Komisija) i Savet EU, i nastoji da ostvari veći uticaj u političko-pravnom životu Unije. Osnivanjem odbora se reflektuje načelo podele vlasti i ostvaruje pun demokratski kapacitet Parlamenta.

\section{2) POJAM ISTRAŽNOG TELA EVROPSKOG PARLAMENTA}

Istražni komitet Evropskog parlamenta se razlikuje od tradicionalnog pojma anketnih komisija u međunarodnom javnom pravu. Međunarodna anketna komisija, kao diplomatski metod rešavanja sporova, predstavlja telo obrazovano radi objektivnog utvrđivanja činjenica koje su uzrokovale međunarodni spor ili utiču na rešenje istog. ${ }^{3}$ Obično je čini neparan broj eksperata (tri ili pet) iz oblasti značajne za predmet spora, koji ne moraju biti striktno pravnici. Njihova se funkcija iscrpljuje u utvrđivanju činjeničnog stanja i izradi izveštaja neobavezne pravne prirode za strane u sporu. Anketna (istražna) komisija ne predlaže rešenje spora, mada su stranke, posebno zbog pritiska međunarodne zajednice, uglavnom saglasne sa izveštajem ovog tela. ${ }^{4}$ Pitanja u vezi sa radom istog u potpunosti su u rukama strana u sporu.

Za razliku od međunarodnih, istražna tela Evropskog parlamenta ispituju činjenice sa stanovišta primene komunitarnog prava. Obrazuju se konstitutivnim ugovorima ili pojedinačnim aktom Parlamenta i rezultat su jačanja pozicije ove u odnosu na ostale institucije Unije. U skladu sa članom 226 Ugovora o funkcionisanju Evropske unije (u daljem tekstu UFEU), Parlament može osnovati istražni odbor privremenog karaktera radi ispitivanja navodnog kršenja ili nepravilnosti u primeni prava EU. Dok kršenje predstavlja postupanje suprotno pravu EU, interesantno je da se pod nepravilnostima podrazumeva širok spektar radnji: zloupotreba vlasti; diskriminacija; administrativna nepravilnost; nepravedno, neispravno ili

\footnotetext{
${ }^{3}$ Boris Krivokapić, „Istraga kao način mirnog rešavanja međunarodnih sporova”, Vojno delo, Vol. 68, No. 5, 2016, str. 71.

${ }^{4}$ Primer za to je špansko-nemački spor o potapanju norveškog broda Tajger (Tiger), koji je potopljen zbog sumnje da se bavio nelegalnim prometom robe. Nemačka, koja je potopila brod, smatrala je da je to učinjeno na otvorenom moru, dok je Španija smatrala da je potopljen u vodama Španije. Izveštaj istražne komisije je utvrdio da je to učinjeno u vodama Španije, sa čim su se strane u sporu saglasile. U sporu između Holandije i Nemačke o torpedovanju holandskog broda „Tubancija” (Tubantia), petočlana istražna komisija je utvrdila odgovornost Nemačke za protivpravni akt i naložila joj da Holandiji isplati odšetu. Nemačka je, poštujući izveštaj komisije, to i učinila. Videti: Ibid., str. 76-77.
} 
nekompetentno postupanje; propuštanje dužnog činjenja; nepažnja; odbijanje davanja potrebnih informacija i odlaganje koje se moglo izbeći. ${ }^{5}$ Time se istražuje raznovrsno postupanje institucija EU i država članica. Pravni standard „nepravilnosti” predstavlja svojevrstan "kišobran” koji pokriva i pozitivne i negativne akte. Daljim tumačenjem navedenog člana, primećuje se ustavno načelo podele vlasti, jer predmet istrage ne mogu biti činjenice koje su predmet sudskog postupka, pri čemu se misli na pravosudne postupke u EU. Hipotetički, ako je slučaj pokrenut pred nacionalnim sudom, ne bi bilo smetnje da bude predmet istrage istražnog odbora Parlamenta. Istu prirodu imaju i istrage pokrenute od strane Evropskog ombudsmana (čl. 228 UFEU) i Revizorskog suda (čl. 285 UFEU).

Istražno telo se obrazuje na zahtev jedne četvrtine poslanika (177 od 705 poslanika), koji treba da bude podržan na plenarnom zasedanju. Predviđeni cenzus, uzimajući u obzir pojedine evropske zemlje, predstavlja kompromisno rešenje, ${ }^{6}$ ali označava težnju da se čvrsto utemeljenim predlogom može osnovati odbor. U sadašnjoj političkoj konstelaciji to znači da manjinske grupacije ne mogu podneti ovaj zahtev. Čini se da nema legitimnih prepreka da se ne dozvoli da jedan poslanik podnese zahtev. Holandsko pravo predviđa takvo rešenje. ${ }^{7}$

Stav 4 čl. 208 Pravilnika Evropskog parlamenta ${ }^{8}$ predviđa da odluku o formiranju odbora donosi Parlament na predlog Konferencije predsednika političkih grupa. ${ }^{9}$ Deluje da nema celishodnih razloga za ovakvom odredbom, jer je predviđen dovoljno visok cenzus za podnošenje zahteva. Pogotovo što ne postoje proceduralne garantije da će zahtev četvrtine poslanika biti usvojen. Rešenje je više politički, a manje pravno obojeno, jer je Konferencija predsednika političko telo. Pogodno je što ona ne može promeniti predmet istrage utvrđen u zahtevu. Njena uloga je da utvrdi ispunjenost uslova iz čl. 226 UFEU na osnovu sopstvenog

\footnotetext{
${ }^{5}$ Eva-Maria Poptcheva, "Parliament's Committes of inquiry and special committees", European Parliamentary Research Service, PE-582.007, 2016, p. 4.

${ }^{6}$ Ustavi Letonije i Slovenije predviđaju zahtev trećine, a u Ustav Portugala petine poslanika. 0 tome, Goran Marković, "European Parliament's Control of the European Commission Procedural Aspects", EU and comparative law issues and challenges series, Procedural Aspects of EU Law, (ed. Dunja Duić, Tunjica Petrašević), Vol. 1, 2017, p. 481.

${ }^{7}$ Eva-Maria Poptcheva, "Parliament's Committes of inquiry and special committees", op. cit., p. 16.

8 "Rules of Procedure of European parliament, $9^{\text {th }}$ parliamentary term", February 2020, available at: https://www.europarl.europa.eu/doceo/document/lastrules/TOC_EN.html?redirect, pristupljeno 28. 1. 2020. godine.

${ }^{9}$ Konferencija predsednika je političko telo koje obezbeđuje koordinaciju i nesmetanu saradnju između odbora. Čine je predsedavajući stalnih i posebnih odbora Evropskog parlamenta i sastaje se utorkom, u vreme mini-sednica u Strazburu. Na njenom čelu je predsednik koji se bira iz redova članova na mandat od dve i po godine.
} 
uverenja, uz asistenciju pomoćnih organa Parlamenta. U jednom slučaju, i pored zahteva četvrtine evroparlamentaraca, odbor nije formiran. ${ }^{10}$

Istražni odbor kao privremeno telo je u obavezi da donese odluku u roku od godinu dana od donošenja odluke o osnivanju. Taj rok se može, odlukom Parlamenta, produžiti dva puta po tri meseca, što je koristan mehanizam za sprovođenje dodatnih istražnih radnji radi potpunijeg određivanja činjeničnog stanja.

\section{3) ISTORIJAT I RAZLOZI NASTANKA ISTRAZZNIH KOMITETA}

Istražna tela Parlamenta su nastala kako bi iznivelisala položaj ove u odnosu na druge institucije EU, u prvom redu Komisije. Bilo je nedopustivo da u zajednici kakva je Unija ne postoji značajan element parlamentarne demokratije, oličen u političkoj kontroli izvršne vlasti. Usled nedostataka istražnih aspekata drugih instrumenata političke kontrole, ${ }^{11}$ konstitutivnim ugovorima je uvedena mogućnost formiranja istražnih organa. Time se, brinući za štetan uticaj loše primene komunitarnog prava, tvorevina EU približava evropskom građaninu.$^{12}$ Radom ovih tela se postiže adekvatna provera legitimnosti radnji članica i institucija EU. Korisno je da se kontroli potčine sve oblasti delovanja izvršne vlasti, kako bi se izbegla selektivnost i u potpunosti ispoštovao princip podele vlasti.

Osnivanje istražnih organa nije strano Parlamentu pre nego što je efektivno stekao to ovlašćenje konstitutivnim ugovorima. Nakon uvođenja opšteg biračkog prava 1979. godine, prepoznata je potreba da se EU pozabavi brojnim pitanjima od javnog značaja za svakodnevni život. Obrazovano je devet odbora koji su, između ostalog, za predmet imali: rasizam i ksenofobiju, bolest „ludih krava”, odlaganje štetnog otpada nakon nuklearnog incidenta u kompaniji MOL u Belgiji, oboljenja stopala i usta. ${ }^{13}$ Primetna je heterogenost odbora u istrazi raznih društvenih sfera.

${ }^{10} \mathrm{U}$ slučaju poreske evazije multinacionalnih kompanija poreklom iz Luksemburga, Belgije i Irske, 188 poslanika je zahtevalo formiranje istražnog tela od 45 članova da bi se ispitale protivpravne poreske aktivnosti. I pored podnošenja zahteva četvrtine poslanika, Konferencija predsednika, uvažavajući mišljenje pravne službe Evropskog parlamenta, zahtev je prema čl. 226 UFEU proglasila neosnovanim. Videti: Eva-Maria Poptcheva, "Parliament's Committes of inquiry and special committees", op. cit., p. 13.

${ }^{11}$ Pravo evropskih poslanika da postavljaju pitanja Komisiji, pravo Evropskog parlamenta da bira predsednika Komisije; mogućnost izglasavanja nepoverenja Komisiji; obaveza Komisije da podnosi redovni godišnji izveštaj Parlamentu predstavljaju ostale elemente političke kontrole.

${ }^{12}$ Elisabeth A. Vallet, "The European Democracy and the Parliamentary Commissions of Inquiry", Revue du droit public et de la science politique en France et a l'etranger, Vol. 5, 2002, p. 1445.

${ }^{13}$ Christian Lequesne, Philippe Rivaud, "The Committees of Independent Experts: expertise in the service of democracy?", Journal of European Public Policy, Vol. 10, No. 5, 2011, p. 699. 
U praksi je istražni odbor formiran pet puta. Najsvežiji slučajevi kojima su se bavili su „Panamski papiri” (Panama Papers) ${ }^{14}$ i „Folksvagenova afera” (Wolkswagen emission scandal) poznatija kao (i u daljem tekstu) „Dizelgejt“ (Dieselgate). ${ }^{15} \mathrm{U}$

${ }^{14}$ Istražni odbor za istraživanje kršenja i nepravilnosti u primeni prava Unije u vezi sa pranjem novca, izbegavanjem poreza i utajom poreza je osnovan 2016. godine na čelu sa predsedavajućim Vernerom Langenom (Werner Langen) da ispita da li otkrivene informacije iz afera „Panamski papiri” predstavljaju kršenje komunitarnog prava. Afera je dovela do objavljivanja 2,6 miliona terabajta sa preko 11 miliona dokumenata koji potiču od advokatske firme Mozak Fonseka (Mossack Fonseca), pružaoca usluga brojnim posrednicima da bi se prikrila stečena dobit fizičkih i pravnih lica, u cilju minimiziranja plaćanja poreza i pranja novca. Otkriveno je mnoštvo jurisdikcija sa poreskim sistemima pogodnim za pranje novca (poreski rajevi), utaju poreza i izbegavanje plaćanja poreza (poreska evazija), smeštenim kako u Panami, tako i na Britanskim Devičanskim ostrvima i Sejšelima, na kojima su osnovane tzv. ofšor (offshore) kompanije. Odbor je analizirao povezanost poreskih rajeva sa članicama EU. Ustanovljeno je da Velika Britanija, Luksemburg i Kipar prednjače u osnivanju ofšor-firmi zbog čega EU gubi enormnih 160 milijardi evra. U izveštaju Odbora države članice su oglašene krivim za kršenje „Treće Direktive o administrativnoj saradnji u oblasti oporezivanja” i „Treće Direktive o sprečavanju korišćenja finansijskog sistema za pranje novca ili finansiranje terorizma". Komisija je odgovorna za propuštanje nadgledanja primene ovih akata. Članice su netransparentno postupale u pogledu međusobne i saradnje sa institucijama EU i nisu pokrenule postupke za identifikovanje sumnjivih transakcija. Usled ubistva malteške novinarke, Dafne Karuana Galicije (Daphne Caruana Galizia), Odbor je preporučio efektivniju zaštitu uzbunjivača. Osim toga, predložio je uspostavljanje jedinstvene definicije za ofšor- finansijske centre, usvajanje novih pravila za regulisanje posrednika u transakcijama, potpuno nov registar stvarnih vlasnika, kao i formiranje stalnog istražnog odbora Evropskog parlamenta.

${ }^{15}$ Slučaj datira iz 2015. godine, kada je Parlament osnovao Istražni odbor za merenje emisija u automobilskom sektoru. Predmet istrage su bile manipulacije proizvođača automobila Folksvagen (Wolkswagen) u pogledu merenja emisija čestica azotnog oksida iz dizel automobila. Istraga na nivou EU se nadovezala na skandal ovog proizvođača na teritoriji SAD, kada je otkriveno da njegovi dizel automobili ispuštaju 40 puta više čestica azotnog oksida u stvarnim, u odnosu na laboratorijske uslove. Američka agencija za zaštitu životne sredine ustanovila je masovnu upotrebu softverskih poremećajnih uređaja (defeat devices), koji onemogućava kontrolu emisija u stvarnim uslovima vožnje. Prema propisima SAD, Folksvagen je time prekršio Zakon o čistom vazduhu ove zemlje, o čemu je izdato Obaveštenje septembra 2015. godine. Zabrinut zbog toga, Parlament je obrazovao istražni odbor na čelu sa Holanđankom Ketlin Van Brempt (Kathleen Van Brempt) da ispita primenu „Uredbe 715/2007 o homologaciji motornih vozila u pogledu emisija iz lakih putničkih vozila i komercijalnih vozila i o pristupu informacijama o popravci i održavanju vozila”, kao i „Direktive 2007/46/EC o uspostavljanju okvira za homologaciju motornih vozila i njihovih prikolica, kao i sistema, komponenti i zasebnih tehničkih jedinica namenjenih za takva vozila". Ispitivano je ponašanje članica u vezi sa zabranom poremećajnih uređaja i da li su iste propisale i sprovele kazne propisane „Uredbom 715/2007”. Analiziran je nadzor Komisije nad primenom pomenutih akata. U izveštaju je utvrđena odgovornost i država članica i Komisije, jer su im manipulacije bile poznate barem jednu deceniju. Države članice nisu adekvatno nadzirale poštovanje 
prethodnoj deceniji ovo telo se bavilo krahom jednog osiguravajućeg društva, ${ }^{16}$ dok su slučajevi „Tranzitni režim Zajednice ${ }^{17} \mathrm{i}$ „Goveđa spongiformna encefalopatija” (u daljem tekstu GSE), ${ }^{18}$ prvi u kojima je istražni odbor formiran.

Mastrihtskim sporazumom (1992) države članice su zvanično priznale Evropskom parlamentu pravo na formiranje istražnih odbora. Članom 138c stvoren

\begin{abstract}
zabrane poremećajnih uređaja, niti su vršili istrage, kažnjavanje i opoziv vozila po tom pitanju. Komisija nije nadgledala poštovanje odredaba pomenutih akata, uzdajući se u aktivnost članica. Važne preporuke Odbora su: hitro donošenje nove regulative o kvalitetu vazduha i stvarnim emisijama iz automobila; usvajanje novih pravila o homologaciji; finansijska odšteta oštećenima u ovoj aferi; jačanje zaštite potrošača.

${ }^{16}$ Predmet istrage istražnog odbora iz 2006. godine, na čelu sa predsedavajućom Mejridom MekGinis (Mairead McGuiness) predstavlja primena "Treće Direktive o životnom osiguranju” od strane regulatornih vlasti Velike Britanije, usled kolapsa osiguravajućeg društva "Pravičan život” (Equitable life). Ova kompanija je ostala dužna više od milijardu i po funti na ime polisa preko milion stanovnika u ovoj, i više od petnaest hiljada stanovnika u drugim evropskim državama. Izveštaj je oglasio Veliku Britaniju odgovornom zbog nepoštovanja Direktive i podsticanja slabog regulatornog okruženja. Utvrđeno je propuštanje dužnog činjenja institucija drugih zemalja, posebno u Irskoj. Ukazano je na preporuke koje je poželjno ispuniti, kako na strani Velike Britanije, tako i na strani EU. Velika Britanija je dužna da nadoknadi štetu oštećenima, ma u kojoj se zemlji oni nalazili. Osim toga, ova zemlja je, pored stvaranja pouzdanijih pravnih standarda u oblasti osiguranja, dužna da obezbedi jasniji pristup pravosudnim organima svim oštećenima. Komisija je neadekvatno sprovela nadzor nad primenom navedenog akta.
\end{abstract}

${ }^{17}$ Odbor je osnovan 1996. god. na čelu sa Džonom Tomlinsonom (John Tomlinson) da istraži kršenje propisa o unutrašnjem tržištu prilikom tranzita robe unutar Zajednice. Ukazano je na zastarelost tranzitnog sistema, koji ne može da odgovori na osamnaest miliona operacija godišnje. Istaknuti su propusti Saveta, Komisije, carinskih službi i privatnih kompanija, koji su svojim nečinjenjem podstakli protivpravni tranzit određenih proizvoda, posebno cigareta. U izveštaju Odbora je konstatovana neaktivnost Komisije, jer se nije adekvatno izborila sa izazovima jedinstvenog tržišta, kao i niz preporuka u cilju efikasnijeg funkcionisanja tranzitnog sistema: kompjuterizacija sistema kao i pojačana kontrola ulaza robe u isti; veća odgovornost vlasnika i prevoznika robe; osnivanje zajedničkih istražnih službi protiv nelegalnog prometa robe.

${ }^{18}$ Odbor je osnovan 1997. god. na čelu sa predsedavajućim Rajmerom Bogeom (Reimer Böge). Predmet istraživanja je bila nepravilna primena komunitarnog prava u krizi izazvanoj neurodegenerativnim oboljenjem - goveđom spongiformnom encefalopatijom (GSE). Izveštaj je ukazao na odgovornost Velike Britanije, Saveta i Komisije. Odgovornost Velike Britanije, kao glavnog prouzrokovača GSE, ogledala se u povećanoj proizvodnji brašna u kom se nalazi protein izazivač ove bolesti. Njeno Ministarstvo poljoprivrede, svesno rizika, nije ograničilo proizvodnju brašna. Savet EU je odgovoran zbog neuvođenja kontrolnih i mera zabrane izvoza, iako je bilo jasnih dokaza. Rasprava pred ovim telom nije bilo, čak je i primetna inicijativa istog da umanji budžet za iskorenjivanje ove bolesti. Komisija nije sprovodila preventivnu politiku i svesno je delovala kako bi umanjila postojeće posledice. Posebno je utvrđena odgovornost organizicionih tela Komisije (Stalni i Naučni veterinarski odbor), zbog slabe kontrole rizika i nedovoljne rasprave pred ovim telima. 
je pravni osnov za vršenje političke kontrole putem tela koje predstavlja kamen spoticanja između Parlamenta, Saveta EU i Komisije. Detaljnije odredbe o vršenju ovog ovlašćenja trebalo je da budu usvojene u međuinstitucionalnom sporazumu ova tri organa. Pet takvih je doneto 1993. godine, a posle niza pregovora, nakon petnaest meseci, konačni sporazum je usvojen aprila 1995. godine. ${ }^{19}$

\section{4) KOMPOZICIJA ISTRAŽNIH ODBORA - EVROPSKI PARLAMENT U MALOM}

Odredbe čl. 208 Pravilnika Parlamenta ${ }^{20}$ ukazuju da se članovi ovih tela biraju iz redova političkih grupa i slobodnih (nesvrstanih) predstavnika u Evropskom parlamentu. Raspored mandata u odboru proporcionalan je sastavu Parlamenta. S tim u vezi, u svim slučajevima u kojima je odbor osnovan, najviše predstavnika imala je tada najbrojnija politička grupa u Parlamentu - Evropska narodna partija (Group of European People's Party). Recimo, u slučaju „Panamski papiri“ imala je 19 predstavnika, u slučaju „Dizelgejt” (Dieselgate) 18, dok je slučaju „Pravičan život" brojala 8 članova u odboru. Članovi odbora se biraju sporazumom političkih grupa, u čijem odsustvu odluku donosi Konferencija predsednika političkih grupa. Ako političke grupe ne imenuju predstavnike, mesta u odboru ostaju upražnjena. Iste gotovo u potpunosti koriste diskreciono pravo da imenuju članove komiteta. Postoji mogućnost da se za svakog punopravnog člana odabere zamenik, koji ima pravo učešća u raspravi na sednicama, ali bez prava glasa, osim ako je punopravni član odsutan. Zamenici doprinose svestranijem raspravljanju predmeta istrage, ali ne učestvuju u istražnim radnjama. Ovim ograničenjem deluje da se doprinosi učvršćivanju stava političke grupe koju zamenici predstavljaju. Izveštaji se u praksi usvajaju sa značajnom većinom glasalih, ${ }^{21}$ pa eventualni suprotan stav zamenika ne bi drastično promenio ishod, pogotovo što u praksi mali broj zamenika bude prisutan na glasanju. ${ }^{22}$ Odborom predsedava predsednik, kome pomažu jedan ili više potpredsednika.

\footnotetext{
19 "Decision of the European Parliament, the Council and the Commission of 19 April 1995 on the detailed provisions governing the exercise of the European Parliament's right of inquiry (95/167/EC, Euratom, ECSC)", Official Journal L 113, 19.5.1995. Ova odluka uz član 226 TFEU i član 208 Pravilnika Parlamenta, predstavlja pravni osnov na kome se zasniva pojam i funkcija istražnih odbora. Čl. 208 Pravilnika u potpunosti je zasnovan na navedenoj odluci tri institucije EU.

20 "Rules of Procedure of European parliament, $9^{\text {th }}$ parliamentary term", February 2020, available at: https://www.europarl.europa.eu/doceo/document/lastrules/TOC_EN.html?redirect, pristupljeno 28. 1. 2020. godine.

${ }^{21}$ Izveštaji u dva poslednja slučaja usvojena su glasovima: 47 od 55 prisutnih (Panamski papiri) i 40 od 44 prisutinih (Dizelgejt).

${ }^{22}$ Najviše ih je bilo na glasanju usvajanja izveštaja u slučaju Panamski papiri - 16, od kojih je samo jedan glasao protiv.
} 
Radi organizacije aktivnosti odbor može imenovati biro, koordinatore i izvestioce. Njima se poveravaju zadaci o kojima će referisati predsedniku ovog tela. Iako strukturom odbor osim političkog ima i administrativni karakter, koordinacijom poslova teži se većoj produktivnosti u radu.

Sastav odbora osigurava demokratski legitimitet i učešće svake političke grupe Evropskog parlamenta. Time se pruža mogućnost da se svi predstavnici, shodno snazi u Parlamentu, upoznaju sa kršenjem komunitarnog prava i daju utemeljene argumente za otklanjanje nepravilnosti. Ovim će svaka država članica biti obaveštena o istražnim radnjama. Takvo rešenje jeste demokratsko, ali se nameće zaključak da ima prostora za drugačiju kompoziciju istražnih tela. Naime, bilo bi poželjno da sastav komiteta čine i eksperti iz oblasti predmeta istrage. To bi nesumnjivo uticalo na kvalitetnije sprovođenje istražnih radnji i izradu izveštaja. Heterogenost predmeta istrage i njihov značaj za javni interes, kao i čitavo građanstvo EU u svih pet slučajeva do sada, zahteva pristup visokokvalifikovanih lica. Teško je verovati da poslanici poseduju specijalizovano znanje iz recimo oblasti poreskog oporezivanja ili auto-industrije, iako i među njima svakako ima kvalifikovanih ljudi. Svaka politička grupa bi mogla imenovati nekolicinu eksperata čije angažovanje ne bi zavisilo od uloge Konferencije predsednika političkih grupa. Iako se u istrazi mogu zahtevati izrade ekspertskih studija, neposrednijim učešćem eksperata u odboru rezultat istrage bi mogao biti delotvorniji. Sasvim sigurno bi to uticalo na kvalitet preporuka i njihovo podrobnije usvajanje.

Broj članova odbora varira u zavisnosti od prirode i obima istražnih radnji. Hronološki posmatrano, broj je rastao od početnih 17 poslanika koji su se bavili tranzitnim sistemom Zajednice, preko 19 u slučaju GSE, 22 u slučaju „Pravičan život”, 45 u aferi „Dizelgejt” (Dieselgate), do konačnih 65 u slučaju „Panamskih papira". To je uslovljeno brojnijim aktivnostima koje treba izvesti u relativno kratkom roku od maksimalnih godinu i po dana. Kako je u poslednja dva slučaja bilo neophodno saslušati desetine svedoka i veštaka, pregledati hiljade dokumenata i organizovati posete velikom broju zemalja, očigledna je potreba za brojnijim ljudskim resursima. Uz pomenutu organizaciju, brojniji istražni odbor implicira lakše i brže obavljanje istražnih radnji, a samim tim i bržu izradu izveštaja. Međusobna razmena iskustava, timski rad i manja opterećenost pojedinaca su pozitivni aspekti tendencije povećanja broja članova odbora, što može uticati na kvalitetniju argumentaciju u izveštaju i kasnijim preporukama.

\section{5) OVLAŠĆENJA ISTRAŽNIH KOMITETA - NEDOVOLJNO OŠTAR MAČ U RUKAMA EVROPSKOG PARLAMENTA}

U toku istražnog postupka odbor može saslušavati svedoke, veštake i eksperte, primati pisane podneske, tražiti neophodnu dokumentaciju, organizovati posete $u$ cilju sprovođenja istražnih radnji. Prema sporazumu navedene tri institucije EU 
(1995), istražni komitet nema striktno pravo da zahteva konkretnog svedoka, već institucije i države članice ovlašćuju zvaničnika ili službenika da se pojavi pred odborom. Odbijanje institucije ili države članice da pošalju imenovano lice na svedočenje se ne može sankcionisati. Takvim postupanjem se krši princip lojalne saradnje predviđen čl. 4, st. 3 Lisabonskog ugovora, čime se otvara dvostruka mogućnost Evropskom parlamentu. Jedna je da obavesti Komisiju da pokrene postupak protiv države članice zbog kršenja odredbe čl. 258 UFEU, a druga da pokrene postupak pred Sudom pravde Evropske unije. ${ }^{23}$ Prva opcija do sada nije korišćena u praksi. Druga mogućnost je nepovoljna zbog eventualne dužine postupka pred pravosudnim organom. Čini se da bi se time prekoračio predviđeni rok od godinu dana, produžen za šest meseci. Eventualni politički pritisak koji bi Parlament nametnuo Komisiji u vidu glasanja nepoverenja i eventualnog raspuštanja, mogao bi da urodi plodom. ${ }^{24}$ Drugi nedostatak svedočenja je odbijanje pozvanih lica da odgovore na pitanja iz razloga poverljivosti ili zaštite javne ili nacionalne bezbednosti. Kao i u prethodnom slučaju, ne postoji adekvatna sankcija za takvo postupanje. Treća slabost je nemogućnost sankcionisanja lažnog iskaza svedoka. Zakletva se ne polaže, pa se ova istražna radnja svodi na puko odgovaranje na postavljena pitanja. Odbor nije pravosudni već politički organ, koji ne ocenjuje krivičnu odgovornosti. Navedeno o svedocima se mutatis mutandis odnosi na veštake. Uprkos manama, u praksi se saslušavanje svedoka pokazalo korisnim. Iako je bilo pojedinačnog odbijanja lica da se pojave pred odborima, mnogo je više onih koji su se odazvali pozivima. Predsednik Evropske Komisije u vreme slučaja „Panamski papiri”, Žan Klod Junker (Jean-Claudes Juncker), premijer Luksembruga 1995-2013, kao i nadležni komesari iz oblasti ekonomskih, finansijskih poslova i zaštite potrošača Pjer Moskovici (Pierre Moscovici) i Vera Jurova (Věra Jourová) su iskazima, ako ništa drugo, ispoštovali načelo lojalne saradnje. Mada su prilično žustro branili reforme EU povodom skandala, priznali su da Komisija nema dovoljno resursa da se izbori sa finansijskim izazovima i da članice slabo implementiraju EU regulative, što je ušlo u izveštaj Odbora. Kooperativni su u istrazi bili i ministri finansija 25 zemalja, pa su njihovi odgovori na upitnik Odbora pomogli u rasvetljavanju uloge pojedinih posrednika iz zemalja čiji su predstavnici. Odbor je organizovao susret sa kolegama iz Belgije koji su se takođe bavili ovim slučajem, na nacionalnom nivou. To je bila prilika da se razmene iskustva i ostvari uticaj odbora EU na nacionalna tela, kako bi se podstakla koordinisana saradnja sa međunarodnim institucijama. Pozitivna je i saradnja sa predstavnicima Komisije u slučaju „Dizelgejt” (Dieselgate). Poziv za saslušanje su prihvatili i pojedini bivši

\footnotetext{
${ }^{23}$ Eva-Maria Poptcheva, "Parliament's Committes of inquiry and special committees", op. cit., p. 6.

${ }^{24}$ Poznat je slučaj raspuštanja Komisije na čelu sa predsednikom Žakom Santerom Uacques Santere) 1999. godine, kada je Parlament odbio da odobri budžet, optužujući Komisiju za proneveru.
} 
komesari (Antonio Tajani, Stavros Dimas). Da politički pritisak Odbora može uroditi plodom, pokazao je pristanak bivšeg komesara za industriju i preduzeća (20042010) Gintera Verhugena (Günter Verheugen) da učestvuje u istrazi, iako je prvobitno odbio poziv. Saslušanjem 64 svedoka i eksperata utvrđeni su značajni podaci o nedostacima u laboratorijskim ispitivanjima emisija iz dizel vozila i propustima nacionalnih vlasti za homologaciju.

U pogledu ostalih ovlašćenja postoje slične manjkavosti. Zahtevanje dokumentacije može se zbog nedostatka sankcije odbiti iz razloga nacionalne sigurnosti ili poverljivosti. Organizovanje poseta limitirano je nedostatkom sopstvenog budžeta, manjkom osoblja i logističke podrške. Istražni komiteti ne mogu da računaju na stalnu podršku ostalih pomoćnih tela institucija EU. Iako nije izričito predviđeno kao ovlašćenje u pomenutoj odluci iz 1995. godine, Odbor je radi istrage o poreskim rajevima posetio sedam država, posebno aktivnih $u$ sumnjivim poreskih aktivnostima, među kojima su SAD, Malta, Luksemburg i Kipar. Cilj ovih misija je da se usled ograničenog vremenskog okvira za sprovođenje istražnih radnji Odbor na licu mesta uveri u postupanje državnih institucija. Zajedničke preporuke iz sprovedenih misija, poput zaštite uzbunjivača i slabe primene standarda dužne pažnje, ušle su u završni izveštaj.

Odbor za ustavna pitanja na čelu sa specijalnim izvestiocem, Britancem Dejvidom Martinom (David Martin), predložio je usvajanje uredbe sa obaveznim dejstvom u članicama. Predlog je odobren 2012, ${ }^{25}$ a u formi rezolucije, ${ }^{26}$ kao podstrek nastavku pregovora između Parlamenta, Saveta EU i Komisije usvojen 2014. godine. Akt je uneo velike promene u korist istražnih tela. U regulativi je predviđeno učešće nacionalnih parlamenata u istrazi u slučajevima eventualne odgovornosti ma kog od organa država članica. Učešće je uslovljeno saglasnošću Saveta i ostvaruje se zaključivanjem sporazuma između istražnog odbora i nacionalnog parlamenta. Novina je ovlašćenje odbora da zatraži, a ne kao do tada, pozove, određeno lice da svedoči. Pod licem se podrazumeva svaka osoba sa

25 “European Parliament's right of inquiry Proposal adopted by the European Parliament on 23 May 2012 for a regulation of the European Parliament on the detailed provisions governing the exercise of the European Parliament's right of inquiry and repealing Decision 95/167/EC, Euratom, ECSC of the European Parliament, the Council and the Commission (2009/2212(INI)) Proposal for a Regulation of the European Parliament on the detailed provisions governing the exercise of the European Parliament's right of inquiry and repealing Decision 95/167/EC, Euratom, ECSC of the European Parliament, the Council and the Commission", Official Journal C 264E, 13 September 2013.

26 "European Parliament legislative resolution of 16 April 2014 on a proposal for a regulation of the European Parliament on the detailed provisions governing the exercise of the European Parliament's right of inquiry and repealing Decision 95/167/EC, Euratom, ECSC of the European Parliament, the Council and the Commission (2009/2212(INL))" , Official Journal L 443, 22 December 2017. 
prebivalištem na teritoriji države članice EU. Odbijanje svedočenja dozvoljeno je pod uslovima koji važe za nacionalna istražna tela, a ne prema pravilima vezanim za sudsko svedočenje. Istovremeno, sankcije za neosnovano odbijanje svedočenja ili davanja lažnog iskaza su proporcionalne kaznama u regulativama članica u vezi sa istražnim telima nacionalnih parlamenata. Međutim, predlog uredbe je manjkav po pitanju obrazlaganja odbijanja svedočenja. On predviđa takvu obavezu jedino za telo ili instituciju EU čiji se zaposleni nije odazvao na poziv istražnog odbora. Ipak, predlog je veliki korak napred u cilju promovisanja ovlašćenja komiteta, koja su garant efikasnijeg i efektivnijeg rada. Međutim, protivljenje ovakvim rešenjima, uz obrazloženje da je suprotno članu 224 UFEU i da predstavlja proizvoljno proširenje ovlašćenja Parlamenta, oštro su iskazali i Savet i Komisija. Dalji napori ka usvajanju konačnog sporazuma ove tri institucije nisu naročito urodili plodom. Aktivna inicijativa Stalnog odbora za ustavna pitanja na čelu sa Danutom Hubner (Danuta Hübner) da u dogovoru sa Savetom i Komisijom ojača ovlašćenja istražnih odbora novim predlogom, ostali su mrtvo slovo na papiru. ${ }^{27}$ Kao odgovor na perzistentno sprečavanje pregovora o spornim pitanjima vezanim za sopstvena istražna ovlašćenja, Parlament je 2019. godine usvojio Rezoluciju. ${ }^{28} \mathrm{U}$ njoj poziva Savet i Komisiju da u skladu sa principom lojalne saradnje nastave pregovore sa novoizabranim parlamentom, jer će u suprotnom razmotriti mogućnost pokretanja postupka pred Sudom pravde EU protiv ovih institucija.

\section{6) IZVEŠTAJI I PREPORUKE ISTRAŽNIH TELA - UTICAJ AKATA MEKOG PRAVA NA PROMENE U EU}

Rezultat rada istražnih odbora predstavlja izrada izveštaja i preporuka koji se na mini-sednicama podnose Evropskom parlamentu na usvajanje. Iako su oba akta neobavezne pravne prirode, mogu biti sredstvo kojim se vrši izmena prava EU. Drugim rečima, organi EU će izdavanjem akta koji sledi preporuke Parlamenta iskazati napore da sprovedu njegove predloge. Takav efekat pripisuje se kako poštovanju načela lojalne saradnje iz člana 4 , st. 3 Lisabonskog ugovora, tako i bojazni Komisije da u slučaju pasivnog postupanja rizikuje izglasavanje nepoverenja. Članice su u saradnji sa institucijama EU dužne prema ovom članu da međusobno sarađuju u ispunjavanju zadataka proisteklih iz konstitutivnih ugovora. Efektivno funkcionisanje komunitarnog prava definitivno spada u takve zadatke.

\footnotetext{
${ }^{27}$ Milan Remáč, "Parliamentary scrutiny of the European Commission: Implementation of Treaty provisions, European, Implementation Assessment update", European Parliamentary Research Service, PE 631.748, 2019, p. 44.

28 "European Parliament resolution of 18 April 2019 on the negotiations with the Council and Commission on the legislative proposal for a regulation on the European Parliament's right of inquiry (2019/2536(RSP)", P8_TA(2019)0440, Text adopted.
} 
Posebno se ističe obaveza članica da se uzdrže od akata kojim mogu ugroziti postizanje ciljeva Unije.

$\mathrm{U}$ ovom poglavlju biće prezentovane promene do kojih su dovele istrage $u$ slučajevima „Panamski papiri”, „Dizelgejt” i „Pravičan život”. Zajedničke karakteristike izveštaja sva tri komiteta su: identifikovanje kršenja komunitarnog prava, oglašavanje država članica ili institucija EU odgovornim za takve povrede i niz predloga za otklanjanje istih.

Najvažnija legislativna promena nakon podnošenja izveštaja Odbora u slučaju „Panamski papiri”, bila je usvajanje Direktive 2018/843 o sprečavanju korišćenja finansijskog sistema za pranje novca ili finansiranje terorizma (Direktiva 2018/843). ${ }^{29}$ Ova, tzv. Peta Direktiva o pranju novca, proširila je domen primene prethodna dva akta koja regulišu ovu oblast - Treće ${ }^{30}$ i Četvrte Direktive ${ }^{31} \mathrm{U}$ izveštaju Odbora posebno su utvrđene povrede Treće Direktive 2005/60/EC o sprečavanju korišćenja finansijskog sistema za pranje novca ili finansiranje terorizma (Direktiva 2005/60/EC) ${ }^{32}$ Države članice su prekršile standard dužne pažnje klijenta (customer due diligence) u pogledu čl. 8 st. 1b, i čl. 9 st.1 ovog akta, koji se odnose na proveru identiteta klijenata pre stupanja u poslovne odnose ili sprovođenja novčanih transakcija. Ovaj standard nalaže pravnim licima da pruže sve informacije o klijentu za koga postoji rizik izlaganja pranju novca ili finansiranju terorizma. Nepoznata vlasnička struktura pogoduje prikrivanju imovine od poverilaca, utaji poreza, izbegavanju sankcija i slično. Veoma je značajno da se takvi podaci dostave nadležnim državnim institucijama, uključujući i Jedinice za finansijsko izveštavanje, koje su prema odredbama Direktive 2005/60/EC, članice dužne da formiraju.

29 "Directive (EU) 2018/843 of the European Parliament and of the Council of 30 May 2018 amending Directive (EU) 2015/849 on the prevention of the use of the financial system for the purposes of money laundering or terrorist financing, and amending Directives 2009/138/EC and 2013/36/EU", Official Journal L 156, 19 June 2018.

30 "Directive 2005/60/EC of the European Parliament and of the Council of 26 October 2005 on the prevention of the use of the financial system for the purpose of money laundering and terrorist financing (Text with EEA relevance)", Official Journal L 309, 25 November 2005.

31 "Directive (EU) 2015/849 of the European Parliament and of the Council of 20 May 2015 on the prevention of the use of the financial system for the purposes of money laundering or terrorist financing, amending Regulation (EU) No 648/2012 of the European Parliament and of the Council, and repealing Directive 2005/60/EC of the European Parliament and of the Council and Commission Directive 2006/70/EC (Text with EEA relevance)", Official Journal L 141, 5 June 2015.

32 "Report on the inquiry into money laundering, tax avoidance and tax evasion", (2017/2013(INI)) A8-0357/2017, European Parliament Committee of Inquiry to investigate alleged contraventions and maladministration in the application of Union law in relation to money laundering, tax avoidance and tax evasion, 8 November 2017, p. 206. 
U skladu sa tim, Direktiva 2018/843, u čl. 18a uvodi dodatne elemente pojačanog standarda dužne pažnje klijenta (predivđenog Direktivom 2015/849), koji podrazumeva prijavljivanje nadležnim vlastima svake transakcije sa pravnim licima iz visokorizičnih trećih zemalja. Da bi se ona ostvarila neophodni su potpuni podaci kako o vlasniku, tako i o prirodi i svrsi poslovnog odnosa, kao i neophodnog odobrenja najvišeg nivoa menadžmenta pravnog lica. Nad takvim poslovnim odnosom institucije EU i država članica vršiće permanentan nadzor. Ovo rešenje omogućava efikasniji monitoring nad sumnjivim transakcijama i njihovu bržu identifikaciju.

Naredna promena koju uvodi Direktiva 2018/843 tiče se obaveze javnog pristupa registrima stvarnih vlasnika koje su sve članice dužne da obezbede Direktivom 2015/849, čime se štiti javni interes. Nedostatak registara je u izveštaju kvalifikovan kao ključan doprinos izmeštanju milijardi dolara u poreske rajeve. Pristup obuhvata potpune podatke o vlasniku (ime, prezime, državljanstvo fizičkih lica, naziv i sedište - pravnih lica) i prirodi njegovog poslovanja. Pristup registrima neće biti uslovljen, osim ako nije reč o registru trustova (trust), za koji je neophodan zahtev za pristup registru, kao dokaz legitimnog interesovanja. Međutim, države nisu revnosno izvršile obaveze. EU je za sedam država koje nisu implementirale nijednu meru (Holandija, Mađarska, Kipar, Portugal, Španija, Slovačka i Rumunija) u februaru 2020. godine dala dodatni rok od dva meseca. Prema istraživanju nevladine organizacije "Global Witness", Slovenija je upozorenje shvatila ozbiljno, pa je zajedno sa još četiri države (Bugarska, Letonija, Danska i Luksemburg) objavila registar stvarnih vlasnika sa javnim pristupom. Pet članica ne dozvoljava pristup registru, dok preostalih sedamnaest još uvek nije ni objavilo registar ${ }^{33}$ Posebno istaknuta u izveštaju Odbora, Velika Britanija je u potpunosti implementirala Direktivu.

Direktiva 2018/843 je u čl. 32a takođe predvidela zabranu anonimnih računa ili sefova i obavezu da se do 10. septembra 2020. godine, objave centralni registri ili elektronski sistemi kojima će nadležne institucije, uključujući Jedinice za finansijsko izveštavanje, imati direktan pristup. Time se omogućava identifikacija bilo kog korisnika koji upravlja bankovnim računom. Ovaj registar, uz registar stvarnih vlasnika, treba da obezbedi potpunu transparentnost u finansijskom poslovanju. EU nastoji da putem centralizovanih elektronskih sistema odgovori na brojne finansijske izazove u želji da spreči narušavanje jedinstvenog tržišta. Kako bi pojačala saradnju sa nadležnim institucijama, Direktiva 2018/843 proširuje nadležnosti Jedinica za finansijsko izveštavanje, koje će imati direktan pristup

${ }^{33}$ Dominic Kavakeb, "Patchy progress in setting up beneficial ownership registers in the EU, Member States must speed up money laundering reforms", 20 March 2020, Article at: https://www.globalwitness.org/en/campaigns/corruption-and-money-laundering/ anonymous-company-owners/5amld-patchy-progress/, pristupljeno 25. 3. 2020. 
navedenim registrima. Države članice su dužne da opskrbe ova tela dostupnim podacima i obezbede uslove za njihovo funkcionisanje. Uzimajući u obzir da je Malta jedna od država koja je odbila saradnju sa finansijskim institucijama zbog umešanosti svog ministra u sumnjive aktivnosti, ovaj akt u čl. 20a nalaže članicama izradu javnog registra svih funkcija koje imaju politički karakter. To će pomoći lakšoj identifikaciji i monitoringu transakcija subjekata sa ove liste, kada takođe treba primeniti pojačan standard dužne pažnje.

Jedna od preporuka ${ }^{34}$ koju je izdao Parlament tiče se posebne zaštite uzbunjivača. Razočaran smrću malteške novinarke Dafne Karuana Galicije (Daphne Caruana Galizia), Odbor je predložio opsežniju zaštitu ovih lica. Definisani u izveštaju kao lica koja obelodanjuju ili prijavljuju različite vrste nepravdi, između ostalog i poresku utaju, uzbunjivači spadaju u kategoriju osoba koje zaslužuju punu podršku u obavljanju svojih aktivnosti. U tom cilju je usvojena Direktiva 2019/1937 o zaštiti osoba koje prijavljuju kršenje prava Unije (Direktiva 2019/1937), ${ }^{35}$ koja predstavlja prvi harmonizovan akt u ovoj oblasti. Njene odredbe štite ne samo uzbunjivače, već i lica povezana sa njima u kontekstu radnog odnosa koja prijavljuju povredu prava EU u različitim društvenim oblastima - finansijskih usluga, zaštite životne sredine, javnog zdravlja ili javnih nabavki. Obuhvatanjem povezanih lica Direktiva 2019/1937 nastoji da zaštititi sva lica koja rade za dobrobit javnog interesa. Prema devetom paragrafu ovog akta, obaveza uspostavljanja efikasnih unutrašnjih i spoljašnjih kanala izveštavanja postoji za pravna lica za više od pedeset zaposlenih, odnosno za opštine sa više od deset hiljada stanovnika. Hijerahijski se uzbunjivač podstiče, mada nije u obavezi, da najpre koristi kanale izveštavanja unutar pravnog lica, pa tek nakon toga spoljašnje kanale za koje je država dužna da obezbedi relevantna nacionalna tela. Izveštaj uzbunjivača se potvrđuje sedam dana od prijema, nakon čega se u zavisnosti od vrste izveštavanja, preduzimaju mere kojima se utvrđuje pouzdanost iznetih informacija. Uzbunjivači su Direktivom 2019/1937 zaštićeni od bilo kakvog vida zastrašivanja, represije ili odmazde. Njima na raspolaganju moraju biti efikasni pravni lekovi, kao i sve nadležne institucije radi savetovanja, pružanja neophodnih informacija i podrške.

Istraga u slučaju „Dizelegejt“ (Dieselgate) utvrdila je odgovornost Komisije ${ }^{36} \mathrm{za}$ propuste u nadgledanju Uredbe 715/2007 o homologaciji motornih vozila u pogledu

34 "European Parliament recommendation of 13 December 2017 to the Council and the Commission following the inquiry into money laundering, tax avoidance and tax evasion (2016/3044(RSP))", Official Journal C 369, 11 October 2018, pp. 178-184.

35 "Directive (EU) 2019/1937 of the European Parliament and of the Council of 23 October 2019 on the protection of persons who report breaches of Union law", Official Journal L 305, 26 November 2019.

36 "Report on the inquiry into emission measurements in the automotive sector" (2016/2215(INI)), A8-0049/2017, 2 European Parliament Committee of Inquiry into Emission Measurements in the Automotive Sector, March 2017, pp. 17, 37, 67. 
emisija iz lakih putničkih vozila i komercijalnih vozila, i o pristupu informacijama o popravci i održavanju vozila (Uredba 715/2007). ${ }^{37}$ Zbog toga je na glasanju za usvajanje izveštaja u Parlamentu, u amandmanima predloženo osnivanje Evropske putne agencije. Ona bi predstavljala centralizovan organ na nivou EU koji bi se bavio nadgledanjem testiranja emisija. Sam predlog je interesantan, zbog toga što bi nadzor nad emisijama vršilo telo nezavisno od institucija EU. Usled žestoke rasprave u Parlamentu, zbog argumenata da osnivanje ove agencije predstavlja dodatne troškove i povećanu birokratizaciju, predlog je odbijen.

S obzirom na to da je dotadašnji laboratorijski ciklus ispitivanja emisija (New European Driving Cycle) pokazao ozbiljne nedostatke jer su odstupanja u stvarnim uslovima prelazila dozvoljenu granicu, EU je usvojila novu regulativu u tom pogledu. Komisija je usvojila Uredbu 2017/1151, ${ }^{38}$ koja je dopunila Uredbu 715/2007 i Direktivu 2007/46/EC. Ovaj akt je predvideo novi, harmonizovan laboratorijski test ciklus ispitivanja emisija iz lakih teretnih vozila (Worldwide Harmonised LightDuty Vehicle Test) koji je značajan, ne samo zbog sposobnosti merenja svih zagađivača vazduha, već je bolje prilagođen stvarnim uslovima u toku vožnje. Reč je o unapređenom test režimu, koji se kao standard za emitovanje ugljen-dioksida i potrošnju goriva ${ }^{39}$ u praksi pokazao veoma efikasnim i nastoji da otkloni nedostatke prethodnog, zastarelog test ciklusa. Stupivši na snagu, postao je obavezan za sve registrovane automobile od 2018. godine. Kako bi osigurala manju emisiju ugljendioksida i azotnog oksida, EU od 2012. godine primenjuje Test stvarne emisije u vožnji (Real Driving Emissions). On se sprovodi pomoću prenosnog sistema za merenje emisija (Portable Emission Measurement System) i u nameri da eliminiše prekomerno zagađenje životne sredine, teži da obuhvati najrazličitije uslove koji se mogu pojaviti tokom vožnje. Test stvarne emisije u vožnji uključuje faktor usaglašenosti (conformity factor), koji omogućava vozilima emisiju veću od dozvoljene količine zagađujućih čestica i odraz je popustljivosti prema

\footnotetext{
37 "Regulation (EC) No 715/2007 of the European Parliament and of the Council of 20 June 2007 on type approval of motor vehicles with respect to emissions from light passenger and commercial vehicles (Euro 5 and Euro 6) and on access to vehicle repair and maintenance information (Text with EEA relevance)", Official Journal L 171, 29 June 2007.

38 "Commission Regulation (EU) 2017/1151 of 1 June 2017 supplementing Regulation (EC) No $715 / 2007$ of the European Parliament and of the Council on type-approval of motor vehicles with respect to emissions from light passenger and commercial vehicles (Euro 5 and Euro 6) and on access to vehicle repair and maintenance information, amending Directive 2007/46/EC of the European Parliament and of the Council, Commission Regulation (EC) No 692/2008 and Commission Regulation (EU) No 1230/2012 and repealing Commission Regulation (EC) No 692/2008 (Text with EEA relevance)", Official Journal L 175, 7 July 2017.

${ }^{39}$ Samo Jereb, "The EU's response to the "dieselgate" scandal", Briefing paper, European court of auditors, 2019, p. 21.
} 
proizvođačima. U vreme istrage u ovom slučaju, primenjeni faktor usaglašenosti iznosio je 2,1, da bi nakon iscrpne argumentacije Odbora taj broj smanjen na 1,0 i primenjivaće se od januara 2020. To je još jedna pozitivna promena koju je uzrokovao rad ovog tela, jer doprinosi emitovanju manje količine čestica azotnog oksida i ugljen-dioksida.

Preostale promene donela je Uredba $2018 / 858{ }^{40}$ U cilju prevencije neusklađenosti sa pravnim standardima, ona obavezuje sve članice i Komisiju da sprovedu zajednički nadzor nad tržištem. Čl. 8 Uredbe 2018/858 predviđa da se na svakih četrdeset hiljada vozila izvrše sveobuhvatni testovi jednog sertifikovanog automobila, barem pet puta godišnje, a da testovi budu obavezni za sva vozila proizvedena od 2021. godine. Izveštaje o proveri homologacije treba da izdaju i proizvođači automobila. Provera usklađenosti već odobrenih vozila sprovodi se radi utvrđivanja da li vozilo ispunjava predviđene kriterijume tokom čitave svoje upotrebe, kako bi se iz saobraćaja isključili automobili koji mogu uzrokovati veću emisiju čestica.

Uredba 2018/858 u čl. 75 daje izvršna ovlašćenja Komisiji koja može da suspenduje ili opozove automobile koji su dobili sertifikat o homologaciji, ako se pokažu da krše propise, uključujući i novčane kazne članicama ili privatnim subjektima u iznosu od trideset hiljada evra po vozilu. To je učinjeno jer članice nisu uspostavile politiku finansijskog kažnjavanja, pa ostaje da se vidi da li će ovakve odredbe doneti promene $u$ tom pravcu. Postoji i mogućnost nadzora nad nacionalnim organima za homologaciju putem timova sačinjenih od predstavnika drugih članica i po potrebi Komisije, što je posledica nepostupanja članica po pravilima Uredbe 715/2007.

Iako je Odbor predložio obeštećenje potrošača pogođenih skandalom, ${ }^{41}$ to se na nivou EU nije dogodilo. Predlog komisije Direktive o reprezentativnim akcijama za zaštitu potrošača predviđa uniforman sistem zaštite, ${ }^{42}$ ali se ona neće primenjivati retroaktivno, što znači da oštećeni potrošači neće dobiti naknadu štete.

\footnotetext{
40 "Regulation (EU) 2018/858 of the European Parliament and of the Council of 30 May 2018 on the approval and market surveillance of motor vehicles and their trailers, and of systems, components and separate technical units intended for such vehicles, amending Regulations (EC) No 715/2007 and (EC) No 595/2009 and repealing Directive 2007/46/EC (Text with EEA relevance.)", Official Journal L 151, 14 June 2018.

41 "European Parliament recommendation of 4 April 2017 to the Council and the Commission following the inquiry into emission measurements in the automotive sector (2016/2908(RSP))", Official Journal C 298, 23 August 2018, pp. 58-67.

42 "Proposal for a Directive of the European Parliament and of the Council on representative actions for the protection of the collective interests of consumers, and repealing Directive 2009/22/EC", COM/2018/0184 final - 2018/089 (COD).
} 
Iako predlog još uvek nije usvojen zbog zastoja u pregovorima Parlamenta, Saveta EU i Komisije, on predstavlja aktivno delovanje po preporukama Parlamenta.

Slučaj „Dizelgejt” (Dieselgate) je različito uticao na države članice. Protiv pojedinih, kao što su Češka, Grčka i Litvanija su pokrenuti postupci zbog nepostojanja sistema novčanih kazni za proizvođače. ${ }^{43}$ Osim Nemačke, Holandije i Italije kojoj su proizvođači isplatili paprene naknade štete, ${ }^{44}$ ostale članice moraju sprovesti detaljne izmene nacionalnih regulativa kako slične afere ne bi imale štetnih posledica po njihov pravni poredak.

Krah osiguravajućeg društva "Pravičan život” ostavio je bez garantovanog iznosa na ime polise životnog osiguranja milione ljudi širom EU. Odbor je u izveštaju Veliku Britaniju oglasio odgovornom i ,toplo joj preporučio" ${ }^{\prime 4}$ preduzimanje mera u obeštećivanju klijenata. Ne samo da je ova kompanija pogrešno poslovala i ugrozila osiguranike u Velikoj Britaniji, već i u Nemačkoj i Irskoj, što je čitavom slučaju dalo prekograničan kontekst. Oštećeni lošom poslovnom politikom bili su kako osiguranici koji su kupili polisu pre nego što je ona doživela kolaps 2001. godine, tako i osiguranici koji su ostali zarobljeni jer nisu mogli da je prenesu na drugo osiguravajuće društvo. Iako je Odbor predložio osmišljavanje šeme radi pravične kompenzacije, istraga u ovom slučaju je tek posredno uticala na isplatu naknade. Tome su, mada ne svim osiguranicima, više doprinele promene unutar Velike Britanije. Presudom Doma lordova (House of Lords) ${ }^{46}$ tada najvišeg suda u Velikoj Britaniji, kompanija je klijentima trebalo da plati preko milijardu i po funti. Prvi korak u tom cilju bilo je donošenje Zakona o „Pravičnom životu” (Equitablje life (Payments) Act) 2010. godine, ${ }^{47}$ koji je predviđao kompletnu kompenzaciju osiguranicima sa učešćem, dok je za ostale pokrivao $22,4 \%$ gubitaka u iznosu od 775 miliona funti. Kako svi osiguranici nisu dobili nadoknadu, kompanija „Pravičan život" je u periodu 2007-2014 ušla u period restrukturiranja kada je deo filijala rasprodat, a deo obaveza prenet na druge osiguravače. Međutim, to nije dovelo do regulisanja svih naknada. Do 2015. godine, ostatak od blizu pola miliona osiguranika još uvek nije isplaćen. Te godine je britanska vlada isplatila još milijardu funti blizu milion osiguranika, ali je i pored toga njih 125.000 ostao neisplaćen. Januara 2020. godine, sve polise ovog društva, osim osiguranika iz Nemačke i Irske,

\footnotetext{
${ }^{43}$ Samo Jereb, "The EU's response to the "dieselgate" scandal", op. cit., p. 19.

${ }^{44}$ Ibid., pp.19-20.

45 "Final report on the crisis of the Equitable Life Assurance Society", A6-0203/2007, European Parliament Committee of Inquiry into the crisis of the Equitable Life Assurance Society, 4. June 2007, part IV, p. 10.

${ }^{46}$ Equitable Life Assurance Society v. Hyman [2000] UKHL 393 All ER 961; [2000] 3 WLR 529 (20th July, 2000).

${ }^{47}$ Equitable Life (Payments) Act 2010 (c. 34).
} 
prodate su kompaniji „Utmost Life and Pensions”. Nemačke i irske polise ostale su vlasništvo kompanije „Pravičan život”, koja je postala filijala društva kome je prethodno prodala polise. Osiguranici su se u ovoj poslovnoj transakciji odrekli određene garantovane stope rasta, a zauzvrat dobili povećanje vrednosti polisa. Iako nije direktno doprinelo izvršenju finansijskih obaveza Velike Britanije, rad Odbora je ubrzao legislativne promene ove članice EU.

U pogledu finansijskog upravljanja, izveštaj Odbora je nakon globalne finansijske krize podstakao uspostavljanje „Sistema evropskog finansijskog nadzora" 2010. godine. ${ }^{48}$ Nastao je nakon ekspertske studije Žaka de Larozijea (Jacques de Larosière), ${ }^{49}$ sa ciljem uspostavljanja koordinisanog i kohezivnog sistema mikro i makrobonitetnog finansijskog nadzora. Sistem je počeo sa radom godinu dana kasnije i sastoji se od Evropskog odbora za sistemski rizik i tri agencije - Evropske bankarske agencije, Evropske uprave za hartije od vrednosti i tržišta i Evropske uprave za osiguranje i profesionalne penzije. Navedeni organi se staraju o usvajanju uniformnih pravila u oblasti finansijskog upravljanja i njihovoj efikasnoj primeni. Krajnji cilj je postizanje jedinstvenog tržišta za finansijske usluge kroz jačanje maksimalne finansijske stabilnosti, finansijske kulture u poslovanju i zaštite potrošača. Elementi sistema finansijskog upravljanja su mikro i makrobonitetni nadzor. Mikrobonitetni nadzor za predmet ima nadgledanje jedne finansijske institucije i njeno izlaganje eventualnim rizicima, kako bi se eliminisale ili umanjile posledice na potrošačku politiku. S druge strane, makrobonitetni nadzor služi proučavanju izloženosti čitavog finansijskog sistema različitim rizičnim pojavama, kako bi se sagledao ukupan uticaj na svetsku ekonomiju. Njega obavlja Evropski odbor za sistemski rizik, dok se preostala tri organa bave mikrobonitetnim nadzorom. Sistemom je predviđen okvir koji će zameniti brojna pravila iz oblasti životnog, neživotnog i reosiguranja. U skladu s tim, subjekti treba da posluju transparentno, vršeći konstantne procene solventnosti i izloženosti riziku. Njihov kapital mora biti prilagođen rizicima, kako bi imali dovoljno sredstava da prevaziđu finansijske probleme. Trenutno je na snazi Direktiva 2019/2177.50

\footnotetext{
48 "Regulation (EU) No 1092/2010 of the European Parliament and of the Council of 24 November 2010 on European Union macro-prudential oversight of the financial system and establishing a European Systemic Risk Board", Official Journal L 331, 15 December 2010.

${ }^{49}$ Jacques de Larosière, et al., "The High-Level Group on Financial Supervision in the EU - de Larosiere Report", Brussels, 2009.

${ }^{50}$ Directive (EU) 2019/2177 of the European Parliament and of the Council of 18 December 2019 amending Directive 2009/138/EC on the taking-up and pursuit of the business of Insurance and Reinsurance (Solvency II), Directive 2014/65/EU on markets in financial instruments and Directive (EU) 2015/849 on the prevention of the use of the financial system for the purposes of money-laundering or terrorist financing (Text with EEA relevance)", Official Journal L 334, 27 December 2019.
} 
S obzirom na to da Velika Britanija nije dosledno spovela Treću Direktivu o životnom osiguranju, ${ }^{51}$ Odbor je predložio upotrebu tzv. tabli korelacije kojima se objašnjava na koji način se vrši transpozicija direktiva u nacionalne pravne poretke. One su odraz načela lojalne saradnje i na osnovu njih se može pokrenuti postupak protiv članica za kršenje prava EU. Iz tog razloga ne postoji obavezna primena tabli korelacija i pored insistiranja Parlamenta. Početni koraci u vidu rezolucija članica i institucija EU učinjeni su još davne 2011. godine, ${ }^{52}$ ali table korelacije još uvek ne primenjuju sve članice. Delom zbog poverljivih informacija u njima, delom zbog toga što se o transpoziciji direktiva može referisati i bez ovakvog sredstva.

\section{7) ZAKLJUČAK}

Istražna tela Evropskog parlamenta predstavljaju važnu kariku u prevenciji kršenja prava EU. Svesni da je svaki konkretan akt pod lupom, subjekti čije je postupanje predmet istrage ne samo da će nastojati da ispoštuju zaključke u izveštaju, već će biti znatno oprezniji i efikasniji u svom budućem radu. Iako su korišćeni u svega pet slučaja u praksi, kvalitativne legislativne promene koje su ova tela prouzrokovala impliciraju da je poželjna njihova češća upotreba. Zaštita javnog interesa EU nalaže sveobuhvatnu implementaciju i poštovanje pravila koja donose njene institucije. U suprotnom, treba delovati pravovremeno, putem pouzdanih, već primenjenih mehanizama. Odbori su se pokazali uspešnim u detektovanju štetnog postupanja i sposobnim da ukažu na pravac u kome je potrebno izmeniti zakonodavnu politiku Unije. Time su se preporučili kao efikasno sredstvo u kontroli izvršne vlasti, iako im još uvek nedostaje potpuni opseg ovlašćenja. Ako je potrebno alarmirati javno mnjenje EU o problemima koji potencijalom mogu napraviti globalne posledice, onda je aktiviranje čl. 226 UFEU pravo rešenje za to. Kao sveprisutni čuvari komunitarnog prava, odbori potpuno legitimno zaslužuju podršku i poštovanje za svoj rad. Posebno od strane Saveta EU i Komisije, koji bi konačno trebalo da prihvate da detaljno regulisanje ovlašćenja odbora ne znači samo jačanje Evropskog parlamenta. EU treba da raspolaže adekvatnim istražnim sredstvima da bi uspešno prebrodila sve prepreke na koje nailazi.

U skladu s tim, nameće se zaključak da je predlog iz izveštaja poslednje tri istrage o formiranju stalnog istražnog odbora utemeljen i svrsishodan. Da bi se

\footnotetext{
51 "Council Directive 92/96/EEC of 10 November 1992 on the coordination of laws, regulations and administrative provisions relating to direct life assurance and amending Directives 79/267/EEC and 90/619/EEC (third life assurance Directive)", Official Journal L 360, 9. December 1992.

52 "Joint Political Declaration of 28 September 2011 of Member States and the Commission on explanatory documents", Official Journal C 369, 17 December 2011; "Joint Political Declaration of 27 October 2011 of the European Parliament, the Council and the Commission on explanatory documents", Official Journal C 369, 17 December 2011.
} 
maksimizovala produktivnost ovih tela, poželjno je opremiti ih makar istim prerogativima koje imaju njihovi pandani u nacionalnim pravima. Ne bude li tako, ostaće sredstvo nedovoljno iskorišćenog kapaciteta. Uzimajući u obzir svakodnevne izazove sa kojima se Unija suočava, fleksibilnost istražnih odbora u kombinaciji sa proširenim nadležnostima, ne nauštrb drugih institucija, mogu predstavljati koristan instrument koji će biti garant konzistentne primene komunitarnog prava i, u širem smislu, zaštite javnog interesa.

\section{8) LITERATURA}

Andone, Corine, "Argumentative Patterns in the Political Domain: The Case of European Parliamentary Committees of Inquiry", Argumentation, Vol. 30, No. 1, 2016, 45-60.

de Larosière, Jacques, et al., "The High-Level Group on Financial Supervision in the EU - de Larosiere Report", Brussels, 2009.

Jereb, Samo, "The EU's response to the "dieselgate" scandal", Briefing paper, European court of auditors, 2019.

Kavakeb, Dominic, "Patchy progress in setting up beneficial ownership registers in the EU, Member States must speed up money laundering reforms", 20 March 2020, Article at: https://www.globalwitness.org/en/campaigns/corruptionand-money-laundering/anonymous-company-owners/5amld-patchyprogress/, pristupljeno 25. 3. 2020.

Krivokapić, Boris, „Istraga kao način mirnog rešavanja međunarodnih sporova”, Vojno delo, Vol. 68, No. 5, 2016, pp. 70-83.

Lequesne, Christian, Rivaud, Philippe, "The Committees of Independent Experts: expertise in the service of democracy?", Journal of European Public Policy, Vol. 10, No. 5, 2011, pp. 695-709.

Marković, Goran, "European Parliament's Control of the European Commission Procedural Aspects,", (ed.) Dunja Duić, Tunjica Petrašević, EU and comparative law issues and challenges series, Procedure Aspects of EU Law, Vol. 1, pp. 471489, 2017.

Poptcheva, Eva-Maria, "Parliament's Committes of inquiry and special committees", European Parliamentary Research Service, PE-582.007, 2016.

Remáč, Milan, "Parliamentary scrutiny of the European Commission: Implementation of Treaty provisions, European, Implementation Assessment update", European Parliamentary Research Service, PE 631.748, 2019.

Vallet, A., Elisabeth, "The European Democracy and the Parliamentary Commissions of Inquiry", Revue du droit public et de la science politique en France et a l'etranger, Vol. 5, 2002, pp. 1441-1457. 


\section{THE EUROPEAN PARLIAMENT'S COMMITTEES OF INQUIRY - THE USEFUL INSTRUMENT FOR CONTROLLING THE APPLICATION OF COMMUNITARIAN LAW}

Summary: According to national legislations, there is also the possibility to form a committee with the aim of conducting an inquiry of a specific issue in communitarian law. In this way, the traditional parliamentary role of oversight of the executive is realized. The European Parliament's committees of inquiry are a reflection of the oversight function and the enlarged legislative prerogatives of this body. Although the result of the work of the investigative bodies is the production of reports which are of a non-binding legal nature, the importance of these bodies is evident both at the institutional level (European Parliament-European Commission relationship) and in terms of encouraging legislative change in the European Union. The aim of the paper is to demystify a specific area to highlight the important role of the committees in detecting numerous adverse impacts under communitarian law, using historical and teleological interpretation, as well as conceptual analysis.

Keywords: committees of inquiry; Communitarian law; The European Parliament; The European Commission; The European Union. 